\title{
A Cognisance of Green Bond Features Preferential to Renewable Energy Project Financing in Ghana
}

\author{
De-Graft Owusu-Manu \\ E-mail: $\underline{\text { d.owusumanu@gmail.com }}$ \\ Lawrence Mankata \\ Email: blazinlawrence@gmail.com \\ David Edwards \\ Email: David.Edwards@bcu.ac.uk \\ Hatem El-Gohary \\ Email: helgohary@qu.edu.qa \\ Javed Hussain \\ Email:javed.hussain@bcu.ac.uk
}

\begin{abstract}
:
Issuance of green bonds (GBs) is valuable for developing countries because it provides a market deepening mechanism, which enables greater liquidity for investments in Renewable Energy (RE) sector. This paper is premised on the outlook for the first GB in Ghana. The study investigates the features of GBs, which investors prioritise as preferential for RE financing (REF). Employing the literature, twelve beneficial features of GBs were identified and formed the based for a questionnaire, which was handed to experts in financial institutions to complete. Data were analysed and ranked with the relative importance index and other statistical tests. The findings illustrated that low-interest rates, similar payback period, economic convenience and transparency issuance are among the top preferential features for feasible green bond rollouts in Ghana. Findings implied that akin to other worldwide cases for renewable energy financing, GBs represent a degree of flexibility, which stems from the homogeneity in their respective features. The study illustrates the specific priorities, which must be considered by potential investors. Resultantly, enabling GBs issuers to develop GB packages that suit the needs of the investment community and ultimately contribute to RE targets' achievement.
\end{abstract}

Keywords: Green Bonds, Green Bonds Features, Financing, Renewable Energy, Ghana Paper type: Research Paper 


\section{Introduction:}

Electricity generation and distribution has long been a key strategic goal in its Ghana's development plan. USAID (2018) show that the current rates of electrification stand at 83\%. Aside from the Seychelles Islands (100\% coverage), data from the World Bank indicate that Ghana has the most extensive and best coverage in the sub-Sahara region (World Bank, 2021). Despite this enormous achievement, the economics of the demand and supply of power has led to four different power crises since independence. Between 2006 - 2016, the country experienced a 52\% increase in energy demand. With limited capacity to supplement the sharp rise in demand within this period, an onset of erratic power crises (the longest in the country's history) became a norm. This led to the now primarily popularised term "dumsor" (translated as on and off). At the peak of the power crises, it was estimated that the country assumed production losses of USD 2 million daily (Kumi, 2017).

Data from Ghana's Energy Commission and the Volta River Authority shows that electricity capacity has seen an exponential increase in response to the power crises over the past decade. The figures show more than a double capacity increase from 2006 to 2019. Electricity capacity increased in the period from 2006 to 2019 by $299 \%$, from only $1730 \mathrm{mw} / \mathrm{y}$ to $5172 \mathrm{mw} / \mathrm{y}$ (Energy Commission, 2020). The grid's overall generation mix comprises of hydroelectric, thermal and solar power (Energy Commission, 2017). By the end of 2019, the various supply sources' proportional distribution stood at 39.9\%, 59.8\% and 0.3\%, respectively (Energy Commission, 2020). In recent years (since 2015), thermal supply has overtaken hydropower as the largest contributor to Ghana's energy generation mix (Kumi, 2017; Ghana Energy Commission, 2017, and 2020). Peak demand stood at $2,613 \mathrm{mw}$ as of the end of 2019 , with a total net consumption of $17,887 \mathrm{GWh}$ against a total net grid supply of 18,188 GWh including imports (Energy Commission, 2020).

Though the capacity has more than doubled in the last few years to meet the current demand, the trends suggest another power crisis is imminent. Annual energy supply reports between 2016 and 2019 show that actually supplied power (i.e. consumed) between 2016 to 2019 rose from 12,705 GWh to 18,188 GWh (Energy Commission, 2020). This represents a total increase of approximately 43\% (14.3\% yearly). To put it in context, between 2006 and 2016, the total increase in demand was 52\% (5.2\% yearly) (Energy Commission, 2016a; Energy Commission, 2017; Kumi, 2017). Yearly demand growth continues to be exponential and would soon catch up to installed capacity in no time, as witnessed with the power crises. Even though installed capacity (mostly thermal) is high, the supplied power is not up to par as operational cost (fuel and maintenance) are exorbitant (Asiedu et al., 2019).

However, in a bid to further committing to energy security, according to Ghana Renewable Energy Master Plan (2019), the country deployed an array of policies targeted at increasing the RE component to $10 \%$ by 2030. Financing RE in Ghana has been mainly from state budgets or international grant aid (Kumi, 2017). Notably, concerning the three main hydropower dams in the country (Akosombo, Bui and Kponge), most financing came from concessional loans and grants 
from: Exim Bank of China; The European Development Bank; The Canadian International Development Agency; and The World Bank (Edjekumhene et al., 2001; and Gyamfi et al., 2018). Investing in RE, according to Tang et al. (2012), requires a significant financial commitment. $\mathrm{Ng}$ and Tao (2016) suggest that financing through banks became not only difficult, but also expensive because of the worldwide economic crisis. Commercial banks now show a more conservative attitude, with greater credit oversight and tightened credit standards regarding adequacy of collateral and borrowers' debt service capacity. In addition, Milford et al. (2014) illustrated that added difficulties are attached, particularly with financing clean energy projects. However, financial sustainability and green investments remain important globally (Ur Rahman et al., 2020). Getting past the traditional financing system's constraints means that more tailored and innovative finance mechanisms need to be explored. This is true for countries as well as firms as such constraints can hinder economic growth (Hussain, et al., 2020; and Aninze, et al., 2018).

For this, the onset of Green Bonds financing has seen popularised use in today's climate mitigating developments. Primarily, they are raised specifically for the financing of environmentally friendly projects (Zachariah, 2016). Griffith-Jones et al. (2012) highlighted that green bonds have proven to show noteworthy potential in offering long-term finance. Currently, the value of green bond issuance is exponentially high since its introduction in 2007. As of 2019, the global value of issuances was pegged at USD 228.2 billion (Deschryver and de Mariz, 2020).

Notwithstanding the positive indications of the above statistics, it is worth noting that Africa is not actively participating in green bonds. With a meagre $0.3 \%$ of global issuances $(\mathrm{Ng}$ and Tao, 2016), the indication is that the growing appetite for green bonds globally is still not actively present on the continent. As of 2019, the CBI estimated the cumulative total green bond issuance (2012 -2019) in Africa at USD 2.1 billion (CBI, 2019). Contextually, the gross value of green bonds ever issued in Africa represents only about $2 \%$ of the value of green bonds raised globally in 2019 (USD 228.2 billion). Notwithstanding the unimpressive numbers, Duru and Young (2016) express that, within the African continent, actively pursuing green bonds for financing environmental projects is highly viable.

In terms of issuances, only six African countries have successfully issued several tranches of green bonds for financing primarily energy projects and other green infrastructural developments (ALCB, 2018; and Climate Bonds Initiative (CBI), 2019). Of these, only four African countries rolled out CBI certified green bond packages. These are South Africa (first issuance 2012), Morocco (first roll out in 2016), Nigeria (first roll out in 2017) and Kenya (first issuance in 2019). Namibia and Seychelles each rolled out green bonds in 2018 though these are not certified (CBI, 2019).

Ghana, yet to issue a green bond but has indicated a future issuance. Though timelines are still unset, this is expected to be achieved within the 2020 -2030 period - with the need for financing SDGs being apparent. It is essential that, with the country's renewable energy capacity and its consequent financial implications, a key focus is given to investor appetite and preferences for green bonds. Milford et al. (2014) suggested that Renewable Energy Projects come with their 
unique set of features from which traditional financing mainly strays away. How does a green bond portfolio fit within this project scope? This study investigates the investor perspective of green bond features, which will be the most suitable for financing renewable energy projects in Ghana.

\section{Empirical Background:}

\subsection{The Paris Climate Agreement and Renewable Energy:}

In an effort to charter a global path and support for redressing global warming, the Paris Climate Agreement (PCA) was born. According to Seo (2017), the agreement was aimed at developing and promoting efforts to keep global warming below $2.0^{\circ} \mathrm{C}$ and, in the process, limit the temperatures to $1.5^{\circ} \mathrm{C}$ (Rogelj et al. 2016). In line with the agreement, Green House Gas (GHG)'s main contributors needed to be sufficiently engaged in the process. China, the USA and the EU contribute $30 \%, 15 \%$ and $10 \%$, respectively, and collectively over $50 \%$ of global emissions (PBL, 2015). Thus, it is not surprising that these significant emitters, including every other country signed on the pact, were required to make available a 5-year basis and enhanced contributory measure (UNFCCC, 2015).

Amongst the leading players in this agreement, the European Union, according to Seo (2017), has shown the most consistency with continuous calls and local measures for binding international climate agreements. Within this regard, the EU agreed to obtain a portion of $20 \%$ of its electricity production from RE.

The United States, until recently, also showed its commitment to the PCA. As part of earlier measures towards the agreement's objectives, the Environmental Protection Agency announced plans to cut GHG emissions up to $45 \%$ by 2025 and expand renewable energy capacity. By issuing the US Clean Air Act plans, new fuel efficiency standards were enrolled as part of the climate mitigation measures. The EPA (2015) highlights that a continuous effort towards renewable energy is pursed with the Clean Power Plan, a new streamlined goal of cutting $\mathrm{CO}_{2}$ emissions for power stations by $32 \%$ between now and 2030 .

In China, 7 preliminary regional carbon emissions trading schemes were launched on a national level in 2017. Ren21 (2015) suggests that the move followed the increase in investments in renewable energy in China, making it the largest spender on the globe. The country also boasted of the largest renewable energy installed capacity. By 2016, China launched its 13th Five Year Plan, which targeted a more robust and streamlined investment and energy efficiency and fuel switching measures.

Ghana has been a supporting and contributing member to this pact. In the first INDC submitted in 2015, the country set out plans for a post-2020 - 2030 timeframe. The plans included a target to reduce the emissions of Green House Gas by $15 \%$ as a typical scenario of 73.95 Metric tons of carbon dioxide equivalent (MTCO2e). With an estimated USD 22.6 billion in investment 
towards meeting its targets, it is expected that USD 6.3 billion is locally raised whilst the remaining USD 16.3 billion is attained from international support. The plan suggests a further $30 \%$ reduction in GHG emissions should external financing be sufficiently provided (GH-INDC, 2015).

A very critical component in Ghana's plans is the focus on sustainable energy security. The target, particularly in this sector, is to achieve a renewable energy component mix of $10 \%$ by 2030. Investments in this are estimated at 2.2 billion dollars to cover the costs of five main programme of action. This includes: 150 - $300 \mathrm{MW}$ small-medium hydro target capacity; 150 - 250MW utilityscale solar power target capacity; 50 - 150MW utility-scale wind power target capacity; $10 \mathrm{MW}$ target capacity from 55 mini-grids solar plants; and 200,000 solar home systems across rural areas. To achieve this, national plans are to be put in place to ensure success (e.g. Feed-in-Tariff Schemes, National Renewable Energy Fund, National renewable energy Act (Act 832), National Energy Policy, Net metering scheme and Renewable Energy Purchase Obligation).

In addition to this, the plan highlights a breakdown of the local finance mobilisation forecasts. In principle, the 1.4 billion USD is anticipated to be eased by the national budget over the period. Meanwhile, 1.7 billion USD is projected to be raised from corporate social responsibility (CSR). The largest part of the money, USD 3.2 billion, is estimated to be raised from commercial facilities locally. Thus, it could be suggested that the plans for raising green finance locally are mainly being considered (GH-INDC, 2015). Especially with a critical focus on renewable energies, the focus on aligning such investments with the nature of financing is very significant. As such, the following question becomes important, how does the RE potential match up to the investor interest in engaging with green bonds on-site?

\subsection{Characteristics of Renewable Energy Projects:}

\section{High Upfront Costs:}

According to published reports, apart from the cheapest energy sources (such as hydro energy sources, biomass and geo-thermal energy sources) and compared to other RE sources, the remaining energy sources are uncompetitive fossil-based systems (UNDP, 2012; and Schwerhoff and Sy, 2017). However, even in the cases of the least cost sources, several factors still play out. Biomass, for instance, needs decent ascendency for maintainable usage, and the availability of land ultimately binds its production (Schwerhoff and Sy, 2017). The land also dictates hydro development as wide scale arid land floods frequently generates the necessity of repositioning indigenous residents resulting in an extra cost in compensations (IPCC, 2011), whereas geothermal sources are not available everywhere. This leaves the option of solar and wind generation, which are nevertheless significantly expensive than fossil-based systems (IPCC, 2011; Collier and Venables, 2012; and UNEP, 2012). Brunnschweiler (2010) also comments on the front-loaded nature of the initial costs of RE as a disadvantage as this makes RE projects more expensive even when other financial terms are similar and hence, looking unattractive to investors.

\section{Long Payback Periods:}


Renewable Energy projects expend over long periods due its implementation technical and economic reiterations. Associated with conservative projects, it takes lengthier times from receiving the initial investments characterized by the magnitude of the seed amount of money. When comparing the 7 - 15 years bond terms with reimbursement for archetypal renewable energy projects, it is found that this period may not be suitable for investors, because stockholders will in most cases favour developments with shorter reimbursement times ( $\mathrm{Ng}$ and Tao, 2016; and Sonntag-O'Brien and Usher, 2006).

\section{Limited Track Record:}

Developers in renewable energy projects resulting from underfinancing typically have a limited track record (Sonntag-O'Brien et al., 2013), which makes them unattractive to investors. Therefore, financiers classify them as high risk. As suggested by Sonntag-O'Brien et al. (2013), lenders generally seek knowledgeable and skilled construction companies with established paraphernalia and knowledgeable workers. More so, bankers of undercapitalized companies can put a project's progress in jeopardy due to compulsory extra progress expenses throughout the project life. Curnow et al. (2010) suggests that the smaller sized RE companies normally face higher contract charges and expenses. This might represent a limitation on such smaller companies when trying to gain extra money from financial institutions.

\section{High Risk:}

Associated finance risks form a large component of RE projects than fossil-based systems. The distinguishing factor accounting for this lies in RE projects' peculiar investment profile (Schwerhoff and Sy, 2017). With renewable energy projects requiring abundant bigger preliminary ventures and fossil-based systems requiring greater yearly cost, the increase in financial costs makes RE projects significantly more expensive, whereas the latter only experiences a moderate increase in expense (Schmidt, 2014). Given the long payback period for renewable energy projects and its associated high capital, investors' risk against the returns may seem too high. This is particularly so for low-income/high-risk countries where other socio-economic factors dictate the returns on investments (Sonntag-O'Brien et al., 2013; UNEP, 2012; Owusu-Manu et al., 2019; Firelake, 2012). The risks are even higher given the need to maintain favourable economics (UNEP, 2012).

\subsection{Green Bonds (GB) Benefits and Advantages:}

Issuance of green bonds is valuable for developing countries. This serves as a market deepening mechanism and provides greater liquidity in those markets, hence facilitating the subsequent issuances for RE's investments (UNEP, 2012). In most cases, green bonds are a winwin choice as they serve as a useful finance vehicle for solving or promoting projects classified as beneficial to the ecosystem. The benefits can be classified to issuer benefits and investor benefits.

\section{Larger Capital Pool at Lower Cost:}


To the Issuer - By issuing green bonds, issuers reach asset owners who might not otherwise have invested in a traditional bond issued by the same firm. Such issuing can vastly diversify their investor pool (ALCB, 2018). Ernest and Young (2016) also allude to the benefit of convenience as an accessible and powerful instrument for financing a sustainable, low-carbon environment and its economy with a comparatively lower cost of raised capital. The world economic forum states that due to the new development in the financial market, the emergence of green bonds might positively affect companies' cost of capital. The green label enables companies to access investors focusing on sustainable investment and thereby broaden the investor base.

Furthermore, increased transparency linked to the green bond will reduce the risk for investors and reduce the cost of debt. Green bonds enable companies to access deep pools of lowcost capital to fund green projects (World Economic Forum, 2015). Access to new investors that focus on responsible investment (RI) is believed to be possible if companies label investments as sustainable; a growing number of investors have shifted focus to RI (Hebb, 2012; and Falsen and Johansson, 2015). Many studies have been conducted on how corporate environmental responsibility affect the financial cost of a company (Oikonomou et al., 2014)

\section{Enhanced Corporate Image:}

To the Issuer - socially responsible investing aligns towards environmentally sound investment opportunities. Investors are not only thinking about making profits; instead, they tend to increase their value and image (Berson, 2009). The concept of RI has seen rapid growth in the past ten years (Sievänen et al., 2012). The issuer will benefit from the bonds' green label as this promotes the social responsibility and environmentally conscious representation of the issuer (Ernest and Young, 2016). This enhances the companies' brand and further increases performance as investors perceive an added value to the company upon issuance (Flammer, 2018).

Institutional investors perceive responsible investing as a proactive form of investment that emphasizes opportunities that offer substantial financial performance and positive secondary benefits (Hebb, 2012). It has also shown that the previous short-term focus of investments distracted the investors from identifying long-term risks and hazards (Woods and Urwin, 2010; and Falsen and Johansson, 2015). Improvement of company reputation refers to company actions to align corporate actions with current societal norms and values (Bansal and Roth, 2000). The company reputation is an essential driver to increase its marketing value (Jenck et al., 2004). A positive company brand takes years to build but can be ruined in a matter of minutes with current media coverage and social media campaigning (Ur Rahman, et al., 2020; Raghubansie, et al., 2013; Weybrecht, 2014; and El-Gohary, 2010). Investor relation and the marketing departments within companies perceive green practices as a communication channel through which they can display environmental initiatives (Ross, 2015; and Falsen and Johansson, 2015).

\section{Better Informed Investment Strategies:}


To the Investor - As green bonds promote transparency through their unique accreditation mechanism, investors are better positioned to implement their green investment strategies. This is made possible with the accessibility to information on the underlying asset (Talal et al., 2016). A better assessment of their risk /return portfolios is made possible while observing their green investment mandates. This enables the implementation of long-term strategies and further provisions facilitating the broadening or deletion of portfolios (Shishlov et al., 2016).

\section{Diversified Investment Portfolios:}

To the Investor - As suggested by Talal et al. (2016), green bonds' nature in supporting climate financing and implementation of climate policies allows investors to open up room in their fixed income portfolio structures. Green bonds promote the private sector financing instruments and provide diversification to the prevailing financial structure. Investors who are attentive towards negative ecological and environmental impacts of corporate activities consider green investment as good opportunities (Silva and Cortez, 2016). The idea is that, in the case of large institutional investors, the increased liquidity provided by green bonds make them more attractive (Clapp, 2014). This is supported by the high demand for green bonds as investors' appetite for environmentally friendly developments continues to grow.

\subsection{Issuances Measures:}

\section{Defining the 'Green' Scope:}

Using the Paris climate example, the green bond market could be reinforced with a shared understanding of objectives and definitions, normal processes and financial recording modules and the market, which may include public-driven development of standards (Shishlov et al., 2016). At the lowest level, market actors should explicitly plan the objectives of the needed standards to explain the true meaning and nature of 'greenness' (Ernest and Young, 2016). Clarifications on investment-compatible areas and priority potentials for sustainable development pathways are essential. The public endorsements of approved and acceptable standards by credible authorities are also necessary (Shishlov et al., 2016).

\section{Providing Stimulating Incentives:}

The CBI and UNEP (2015) described green bonds as the type of bonds with similar return rates as other types of bonds but with an added benefit of providing climate change solutions. Considering added costs that may be experienced, these added benefits should be tangible enough to increase investor participation in green bonds (Chugan et al., 2017). In line with this, green bonds cost can be decreased for these bonds used to finance important green and sustainable RE projects through public support arrangements, which could be offered by governments. This could be undertaken as subsidies, governmental support, tax pauses, modifications in regulations, and/or modifications in public warranties. 
To avoid free-riding and maximise public support efficiency, robust evaluation and reporting will be required in the implementation of such measures (Shishlov et al., 2016). The CBI recommends tax credit bonds, direct subsidy bonds, and tax - exempt bonds to achieve this objective. The provision of tax incentives is to the good of issuers and further deepen the market by making it attractive for foreign investment at the local level (CBI, 2015). Elliot and Zhuang (2014) also conclude that, with a growing green bond market, small-sized projects' amalgamation into a more significant investment is possible and ultimately more suitable for investors with more extensive portfolios.

\section{Priority to Economically Feasible Developments:}

In many developed European countries, strategic projects are outlined. Joint support with investors and development banks sees the appropriate structuring of projects to successfully enroll in the green bond market (CBI and UNEP, 2015). This approach's success has seen rising interest in emerging economies, and typically, in Africa, Kenya is undertaking this process of 'strategic priority projects'. A list of key strategic projects that the government may prioritise over a timeframe may be contemplated with the goals expressed in these strategies/ INDCs (Chugan et al., 2017). An essential element to ensure attractiveness is the financial viability of the projects. This is a critical upstream component that facilitates bond financing, though not a specific market policy action. Government guarantees may be required as revenue sources of green projects are crucial to offsetting any shortfalls in demand.

\section{Public Level Participation:}

Chugan et al. (2017) suggest that in kick-starting green bond market at nascent stages, strategic green bond issuance from public entities can be instrumental. These demonstrative issuances engage potential issuers and investors and further educate them on green bonds benefits, challenges and standard issuance procedures. This signals the market on the governmental priorities of climate change and ecofriendly developments - RE in this case. (CBI and UNEP, 2015).

\subsection{Theoretical Grounding}

Green bonds have exploded in popularity within developed financial markets and continues to expand into developing markets. In this study, the "preferential" factors of green bonds for renewable energy investments are investigated. These preferential features should offset the unattractiveness of both traditional financing and the challenges with renewable energy projects. In effect, motivating investors to participate with green bond issuances for renewable energy projects. While making references to shareholder theory (Freeman, 1984; Li et al., 2020), socially responsible investing (Brzeszczynski and McIntosh, 2014), and CSR (Junkus and Berry, 2015), this present study adapts the theoretical framework of Maltias and Nykvist, (2020) which establishes three drivers for investor engagement with green bond markets, which are: 
- Direct financial benefits,

- Business case benefits, and

- Legitimacy and institutionally oriented incentives.

The work is further linked to the findings of Owusu-Manu et al. (2021) which identify the challenges confronting the financing renewable energy under three components, which are:

- Intrinsic-economic challenges,

- Commercial challenges, and

- Regulatory challenges (refer to Figure 1 for a theoretical conceptual model).

\section{Direct Benefits:}

Maltias and Nykvist (2020) defined the direct benefits of green bonds as those, which reduce financial risk and increase returns of investors. Furthermore, they offer prospects of diversification benefits which are not available in other nonlabelled asset class investments. The lower cost of capital and increased capital access also falls under this categorization. According to Cheng et al. (2014), CSR of firms provides benefits in much lower capital constraints as a result of less agency costs and minimized information asymmetry. Consequently, CSR yields better access to capital. From Owusu-Manu et al. (2021), intrinsic economic challenges are those which are apparent from the very nature of the renewable project itself. These include high upfront costs, long payback periods, risk vs reward imbalance, uncertainty with profitability amongst others. Investor interests in green bonds for renewable projects is therefore linked to the ability access the high capital investment, at affordable rates for which risks are adequately distributed. This can be related to the direct benefits as earlier discussed.

\section{Business-Case Benefits:}

Maltias and Nykvist (2020) identified the business-case benefits as incentives, which are associated with the investor or the issuer performance (which do not necessarily stem from the green bond financial performance). These include:

○ Branding,

- Operational efficiency,

- Creating new markets, and

- Reduced business risk.

Junkus and Berry (2015) suggest that with the principles of socially responsible investing, the inclusionary approach allows firms that are involved in CSR activities (which include green/sustainable practices) are more attractive and preferential for investment. Studies have also shown that, CSR investments form part of the shaping of a reputable social image, thus results in direct proportional financial performance (McWilliams ad Seigel, 2001, Kruger, 2015). The commercial challenges identified are related to lack of investments in renewable energy technologies, ineffective local pricing schemes, and lack of governmental policy (Owusu-Manu et al., 2021). A preferential green bond feature should thus provide the business case benefits such 
that, the commercial performance of the underlying renewable energy asset is improved. These factors can be related to the business-case benefits.

\section{Legitimacy Benefits:}

Legitimacy benefits relate to broader external forces which influence "license to operate" at a collective level and extends outside the scope of specific business strategies (Maltias and Nykvist, 2020). The study identified this category to include accountability to identifiable stakeholders, and institutional pressures. Brzeszczynski and McIntosh (2014) suggest that a socially responsible investing strategy integrates the returns of an investment across financial, social and environmental dimensions. In effect complementing the ethical, social, economic and ecological concerns of an investor. Shareholder theory also posits that, organizations may want to extend shareholder interests and consider benefits which may serve a bigger group of stakeholders (Freeman, 1984). The regulatory challenges were identified to comprise the imperfect markets of corporate bonds, and lack of appropriate structure of regulations (Owusu-Manu et al., 2021). In linking to legitimacy benefits, such preferential green bond features should facilitate legitimacy at the social level, while influencing external forces in both market, and policy levels.

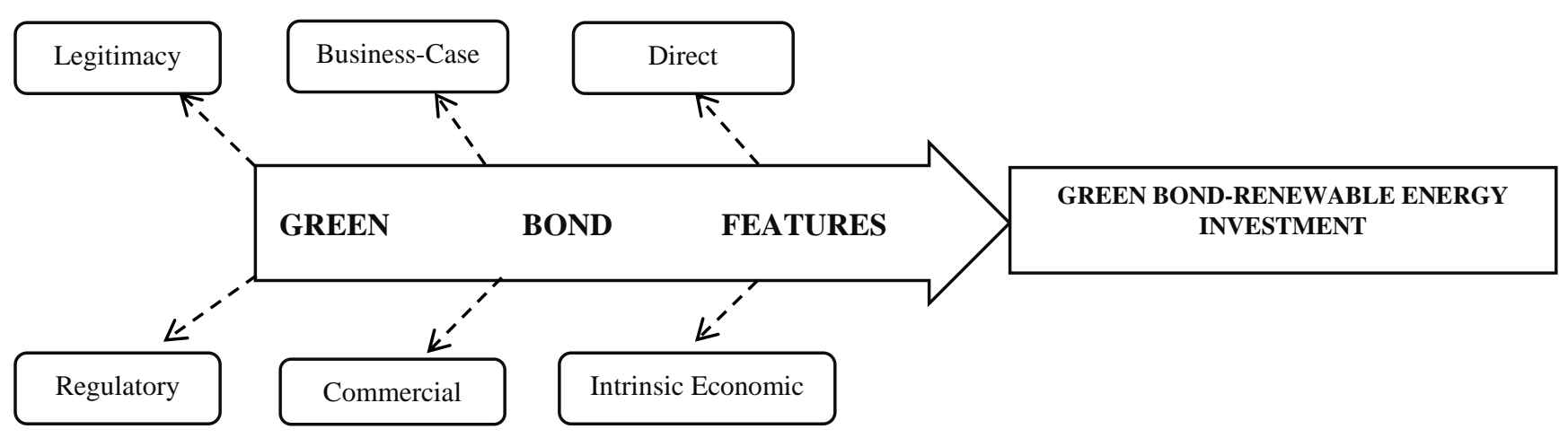

Figure 1. Conceptual Framework

Source: Authors Construct (2021)

The conceptual framework highlights the proposed linkages within the concepts adopted. In this study however primarily investigate the specific green bond features and further propose a detailed investigation of the linkages in further studies. This in turn raises the question:

Which Green Bond Features are statistically significant for promoting green bondrenewable energy investment interest?

\subsection{Methodology:}

For this study, deductive reasoning using a quantitative approach was adopted (Kulkarni et al., 2018; Edwards et al., 2019; and Olanrewaju et al., 2020). Early studies of Cresswell (1994) 
described this approach as a "numerical inquiry" into human or social problems through the use of variable hypothesis and statistical analysis - the process allows for a test into theorized problems. Rajasekar et al. (2013) adds that, it is a "measurement-based" research strategy. This strategy creates room for an extra significant volume of data to be collected in a shorter timeframe (Dawson, 2009). As in accordance with Wilson (2010), this study developed its question, based of extant literature and existing theories coached within an interpretivist philosophy (Edwards and Holt, 2009; Newman et al., 2020), and formulated a plan to test out the assumptions. Consequently, in this approach, conclusions will be deduced from the results of the statistical analysis performed. The research design adopted employed a cross-sectional survey, where a research design is defined as a blueprint utilized in conducting a study within an established and controlled context and scope (Burns and Grove, 2003). This limits the factors that could possibly interfere with the validity of the findings. The cross-sectional design allows for data to be collected from a sample selected to represent a population at one point in time (Owens, 2002).

The population defines the total quantity of a specific demography of people, units or cases relevant to the subject of a researcher (Walliman, 2011). The population frame for this research were registered and recognized financing firms and their members within Ghana. As such, the population frame included pension funds, insurance companies, and banking/financial institutions. Concerning the research sample, the authors used convenience and purposive sample for completing this research. Convenience sampling, utilized as a non-probability sampling procedure that allowed for the inclusion of participants in the research due to their availability as and when the process was undertaken. Purposive sampling, as recommended by Kumar (2011) is utilised with the focus set on a preferential group who are best suited to provide information in line with the research objectives. Depending on such techniques allowed the authors to target, the most influential personnel within the population frame.

The sample size assessment employed the use of the Kish formula (> or +30 samples). Population size data was obtained from annual reports from state regulatory authorities for institutions under consideration. The National Insurance Commission reports that as of 31st December 2017, there were 54 insurance companies registered in good standing (NIC, 2018). The Bank of Ghana report also states several 23 licensed banks in good standing as of January 2019 (BoG, 2019). These companies have different branches spread across the country. The National Pensions and Regulatory Authority also listed as of 2017 an approved 33 number of pension funds and asset management companies in Ghana (NPRA, 2017). As such, the research population frame reached 110 units (the sample size from Kish was determined to be 54).

Closed ended questionnaires were utilised as the data-collecting instrument in this study (Aghimien et al., 2020). Kothari (2004) and Walliman (2011) agree with the use of questionnaires as a suitable, effective and efficient way of collecting quantitative data. The questionnaires comprised two parts - A and B. Part A focused on collecting demographic data, while part B focused on objective-related data. Through a desk study and comprehensive literature search on the underlying objectives being investigated, the features of green bonds were identified and modelled into the questionnaire. The selected factors were such that, they agreed with the 
framework constructs of investor motivating factors - direct, business-case and legitimacy (Maltias and Nykvist, 2020) - and identified challenges to renewable energy financing - intrinsic economic, commercial and regulatory (Owusu-Manu et al., 2021). Table 1 highlights the features and respective sources.

Table 1. Green Bond Features

\begin{tabular}{|c|c|c|}
\hline$N$ & Features & References \\
\hline 1 & $\begin{array}{l}\text { Promoting environmentally conscious } \\
\text { investments }\end{array}$ & $\begin{array}{l}\text { Kidney (2014), Falsen and Johansson (2015), } \\
\text { Ng and Tao (2016), Shishlov et al. (2016), EY } \\
\text { (2018), Panda Breen and Campbell (2016), } \\
\text { (2017), Saha and d'Almeida (2017), Deschryver } \\
\text { and De Mariz (2020), and Tang and Zhang } \\
\text { (2020). }\end{array}$ \\
\hline 2 & Access to a larger investo & $\begin{array}{l}\text { Kidney (2014), Falsen and Johansson (2015), } \\
\text { Shishlov et al. (2016), Deschryver and De } \\
\text { Mariz (2020), and Tang and Zhang (2020). }\end{array}$ \\
\hline 3 & Oversubscription o & $\begin{array}{l}\text { Talbot (2017), EY (2018), Deschryver and De } \\
\text { Mariz (2020), Breen and Campbell (2016). } \\
\text { Wiśniewski and Zieliński (2019), and Wang } \\
\text { (2017) }\end{array}$ \\
\hline 4 & Low i & $\begin{array}{l}\text { Falsen and Johansson (2015), Langhelle } \\
\text { (2016), Ng and Tao (2016), Saha and } \\
\text { d'Almeida (2017), and Panda (2017). }\end{array}$ \\
\hline 5 & Diversified inve & $\begin{array}{l}\text { Kidney (2014), Ross (2015), Shishlov et al. } \\
\text { (2016), Ng and Tao (2016), Panda (2017), Saha } \\
\text { and d'Almeida (2017), and (ALCB, 2018). }\end{array}$ \\
\hline 6 & Enhanced CSR image & $\begin{array}{l}\text { Kidney (2014), Ross (2015), Falsen and } \\
\text { Johansson (2015), Langhelle (2016), Shishlov } \\
\text { et al. (2016), EY (2018), and Flammer (2018). }\end{array}$ \\
\hline 7 & renc & $\begin{array}{l}\text { Kidney (2014), Ross (2015), Panda (2017), and } \\
\text { Talbot (2017). }\end{array}$ \\
\hline 8 & Fixed-rate of retur & $\begin{array}{l}\text { Ng and Tao (2016), Talal et al., (2016), Chugan } \\
\text { et al. (2017), Liaw (2020), and Roboredo } \\
(2020) \text {. }\end{array}$ \\
\hline 9 & Flexibility in issuance & $\begin{array}{l}\mathrm{Ng} \text { and Tao (2016), Saha and d'Almeida } \\
\text { (2017), and Agliardi and Agliardi, (2019). }\end{array}$ \\
\hline 10 & Similar payback pe & $\begin{array}{l}\text { CBI (2013), Ng and Tao (2016), Cochu et al. } \\
\text { (2016), and Sartzetakis (2020). }\end{array}$ \\
\hline 11 & $\begin{array}{l}\text { Growing investor demand for green } \\
\text { investments }\end{array}$ & $\begin{array}{l}\text { Ross (2015), Saha and d'Almeida (2017), EY } \\
\text { (2018). }\end{array}$ \\
\hline 12 & Economic convenience for RE projects & $\begin{array}{l}\mathrm{Ng} \text { and Tao (2016), Panda (2017), and EY } \\
\text { (2018) }\end{array}$ \\
\hline
\end{tabular}

Source: Authors' Construct (2021) 
Following the findings and suggestions from earlier studies in the field, the questions were developed with a closed-ended framework using Likert scale to effectively identify what features of green bonds professionals considered the most preferential for renewable energy financing. Questionnaires were mainly distributed through online survey platforms and in person.

The first point of contact to the respondents was through earlier participatory requests, made to customer service departments of the financial institutions. From this point, the requests were queued and forwarded to the respective administrative department for approval to participate in the survey. Where delivery was made by hand, reception secretaries first received the requests and forwarded to appropriate department as earlier described. If an institution (department) decided to participate, a resource person deemed fit is selected to fill out the questionnaire. This is outside the control of the researchers. However, the personnel who took part had to be recommended by the institution as being capable of providing relevant contribution to the study. Following the explorative nature of the study, room was made to accommodate the opinions of both personnel in top and lower management of the organizations thus, no specific exclusion criteria were set. Participants included CEOs, directors, managers and financial analysts. Furthermore, as part of measures to ensure no breach of ethical considerations, a brief of the study was presented to the respondents after which a secondary consent of participation was solicited. The privacy and confidentiality of answers were assured and gave room for complete transparency and opinion sharing in the study (Fisher et al., 2018).

In all there was a response rate of $60 \%$. Baruch and Holton (2008) estimate a response rate of $35.7 \%$ to $52.7 \%$ for organizational studies. Ease of online delivery and responses could factor into the high rate of response.

Data analysis was completed using SPSS (IBM Corp, 2016). The analysis included descriptive statistics of the responses. The means and standard deviations were represented in the analysis. While the mean represented the response averages, the standard deviations highlighted the independent scores' dispersion against the mean. The relative importance indexes of the variables were obtained through a relationship between the weighted scores, the total number of participants and the peak scale value. The formula gives this.

\section{Relative Importance Index (RII) $=\Sigma$ (The given weight for every factor by the research participants $x$ the highest weight $x$ the total number of participants)}

The higher the value of RII, the more significant the reason of delay was. Meanwhile, the RII is typically a common ranking technique that has been largely employed on bond financing studies (cf. Owusu-Manu 2019; and Alteneiji et al., 2019). Generally, it is applied to Likert type data from which the researcher presumes an equal interval between scales. The RII values range from $0-1$. Thus, the case of higher value represents a higher impact or significance of the variable (Holt, 2014; and Gündüz et al., 2013). 
In addition to this, a one-sample t-test was carried out. This was to test individual variables significance against the overall mean of the measure. For this study, the confidence level was set at 95; thus, significance was established at $\mathrm{p}<0.05$. Testing for the significance of ranked variables is a standard statistical technique utilized in some studies (Moore et al., 2015). By this approach, the factors which still remain significant to the dependent variable are highlighted and extracted (Park, 2015).

\subsection{Results and Discussion:}

Green bonds have been considered ideal for renewable energy projects for their characteristic climate mitigating factors and their payback period. The lack of availability of such financial instruments can be said to be contributory to the underdevelopment of renewable energy projects in Ghana. Therefore, this creates the need to identify its viability should this approach be deployed for providing of finance for RE within the country. This section dissects the factors highlighted by industry finance professionals as vital in ensuring the viability of green bond in the Ghanaian environment.

Table 2: Research Items Reliability Statistics Results

\begin{tabular}{|c|c|}
\hline Coefficient Alpha & Total Number of Items \\
\hline 0.837 & 12 \\
\hline
\end{tabular}

The Coefficient of the scale, as seen in Table 2 above, is 0.837 . This exceeds the reliability standard of 0.700 and hence authenticates the general suitability and consistency present within responses collated (Norušis 2012; El-Gohary, 2012; and Singh, 2017).

Table 3: Relative Importance Index Rankings

\begin{tabular}{|l|c|c|c|c|}
\hline \multicolumn{1}{|c|}{ Features } & Mean & $\begin{array}{l}\text { Std. } \\
\text { Deviation }\end{array}$ & RII & Rank \\
\hline Low interest rate & 4.53 & .718 & .906 & $1 \mathrm{sT}$ \\
\hline Similar payback period with RE projects & 4.41 & .911 & .881 & $2 \mathrm{ND}$ \\
\hline Economical convenience for RE projects & 4.41 & .837 & .881 & $3 \mathrm{RD}$ \\
\hline Transparency in bond issuance & 4.31 & .821 & .863 & $4 \mathrm{TH}$ \\
\hline Fixed rate of return on investment & 4.28 & .634 & .856 & $5 \mathrm{TH}$ \\
\hline Access to a larger investor pool & 4.25 & .672 & .850 & $6 \mathrm{TH}$ \\
\hline Enhanced CSR image & 4.06 & .840 & .813 & $7 \mathrm{TH}$ \\
\hline Diversified investment portfolio & 3.59 & .712 & .719 & $8 \mathrm{TH}$ \\
\hline Growing investor demand for green investments & 3.44 & .878 & .688 & $9 \mathrm{TH}$ \\
\hline Promoting environmentally conscious investments & 3.28 & .772 & .656 & $10^{\mathrm{TH}}$ \\
\hline
\end{tabular}




\begin{tabular}{|l|l|l|l|l|}
\hline Flexibility in issuance & 3.16 & .723 & .631 & $11^{\mathrm{TH}}$ \\
\hline Oversubscription of issuances globally & 2.97 & .861 & .594 & $12^{\mathrm{TH}}$ \\
\hline
\end{tabular}

Table 4: One-Sample t-test Results

\begin{tabular}{|l|c|c|r|}
\hline \multicolumn{1}{|c|}{ Features } & $\begin{array}{c}\text { t-value } \\
(\mathbf{3 . 5})\end{array}$ & $\begin{array}{c}\text { Sig (2- } \\
\text { tailed) }\end{array}$ & $\begin{array}{c}\text { Null } \\
\text { Hypothesis }\end{array}$ \\
\hline Low interest rate & 8.128 & .000 & Significant \\
\hline Similar payback period with RE projects & 5.628 & .000 & Significant \\
\hline Economic convenience for RE projects & 6.125 & .000 & Significant \\
\hline Transparency in bond issuance & 5.601 & .000 & Significant \\
\hline Fixed-rate of return on investment & 6.968 & .000 & Significant \\
\hline Access to a larger investor pool & 6.313 & .000 & Significant \\
\hline Enhanced CSR image & 3.788 & .001 & Significant \\
\hline Diversified investment portfolio & .745 & .462 & Not significant \\
\hline Growing investor demand for green investments & -.403 & .690 & Not significant \\
\hline Promoting environmentally conscious investments & -1.603 & .119 & Not significant \\
\hline Flexibility in issuance & -2.688 & .011 & Significant \\
\hline Oversubscription of issuances globally & -3.491 & .001 & Significant \\
\hline
\end{tabular}

Table 3. shows this analysis together with various means and standard deviations of the variables. Ranking first with an RII score of 0.906 is a low-interest rate with a standard deviation of 0.718 and had a statistical mean of 4.53 . The variable also showed significance $(\mathrm{t}=8.128$, and sig $=0.000$ ). The second is similar payback periods with RE with an RII of 0.881 , the standard deviation of 0.911 , statistical mean of 4.41 and statistically significant $(\mathrm{t}=5.628, \mathrm{sig}=0.000)$. The RE variable's economic convenience variable came in 3rd, having an RII of 0.881 , the standard deviation of 0.837 and significant at $t=6.125$, sig $=0.000$. This was ranked third though it scored the same as the second ranked variable due to its less standard deviation. Ahadzie (2007) makes this suggestion for dealing with equally scored variables during analysis. Transparency in bond issuance was significant in 4th place $(\mathrm{t}=5.601$, sig $=0.000)$, with RII of 0.863 , means and standard deviation of 4.41 and 0.821 , respectively.

From 5th - 10th were: fixed rate of return on investment (significant at $\mathrm{t}=6.968$, $\mathrm{sig}=$ $0.000)$; access to a larger investor pool (significant at $\mathrm{t}=6.313$, sig $=0.000)$; enhanced CSR image (significant at $\mathrm{t}=3.788, \mathrm{sig}=0.001$ ); diversified investment portfolio (not significant at $\mathrm{t}=0.745$, sig $=0.462$ ); growing investor demand for green investments (not significant at $\mathrm{t}=-0.403$, sig $=$ 0.690 ); and promoting environmentally conscious investments (significant at $\mathrm{t}=-1.603$, sig $=$ $0.119)$. 
Their RII scored $0.856,0.856,0.813,0.719,0.688$, and 0.656 respectively. The standard deviations for each of the variables respectively ordered as $0.634,0.672,0.840,0.712,0.878$, and 0.772. The last two variables in are flexibility in issuance in 11th place and significant at $(\mathrm{t}=-$ 2.688 , sig $=0.011)$, and oversubscription of issuances globally in 12th place also significant $(\mathrm{t}=$ 3.491 , sig $=0.001)$. The RII scores of both stand at 0.631 and 0.594 . Their associated respective means and standard deviations are also 3.16-0.723 and 2.97-0.861.

\subsection{Discussion of Results:}

The low-interest-rate of green bonds was considered the topmost viability factor. This has been considered in previous literature as an advantage over traditional finance. Generally, it is also an incentive to cut down costs of project funding in itself, as the bonds tend to be relatively cheaper comparatively (Deliotte, 2017). The rates tend to be lower with the simplification of the processes involved in the issuance procedure. In addition, the specialty of the bond makes it exclusive to investors that specifically want to go green, hence giving more control over the bond's price mechanisms. From the investor perspective, the fixed rate is an assured form of return in itself and provides cover for any shortfall in the market. Hence narrowing margins comparatively to other finance mechanisms in the long run (Chugan et al., 2017). $\mathrm{Ng}$ and Tao (2016) suggest that renewable energy projects be packaged and structured as project finance bonds due to the similarities in their payback periods, making them a cost-effective option. As also suggested in Mankata et al. (2020), the right packaging of green bonds for renewable energy projects is necessary to stimulate investor participation. This opinion was confirmed in the analysis, with this variable being second ranked.

Generally, the 7 - 15-year typical long-term bond periods fall within the scope of RE reconciliation durations. The similarity between the two investors will be better poised in receiving a solid return on their investment. In addition, projects will not be under pressure to provide quick returns, thereby maintaining appropriate liquidity levels throughout the project to cater to the development costs.

Practically, these findings imply that, should there be a green bond package for Ghana's renewable energy projects, key considerations should be given to the above-highlighted factors. Without sufficient fulfilment and provision of the factors raised, investor interest in the issuance may be affected. Interest rates should be kept moderate and relatively low, especially when the state's sovereignty backs the bond. The payback periods should conform to the project dynamics and must be proven profitable within the stated timeframe. To no small extent, these implications fall within the issuer's responsibility, which most likely is the Bank of Ghana (BoG) - through its subsidiary banks - in the first issuance. As the primary regulator, the capacity thus exists to ensure this criterion' provision to see the bank succeed.

Following the trend in duration and interest benefits, green bonds' economic and convenient characteristic was confirmed. This is mainly expressed by the fewer costs incurred in 
green bonds and their climate-friendly structure, specifically favouring renewable energy projects (Shishlov et al. 2016). The economics of green bonds themselves are developed to be beneficial. It is imperative that for the viability of Green Bonds to be ensured in the Ghanaian market, adequate measures are put in place to maintain this factor, thus attracting investors. Transparency in issuance is one of such vital factors looked out for by investors. This mostly falls within the managerial and policy-making functions of the process. First, with a limited track record of renewable energy projects, the financial dynamics must be thoroughly explained to investors to be engaged.

The risks versus rewards factor should be termed out within concealing any critical information. Within the issuance process itself, investors need to conversant and date on any aspect of the process. Investor confidence forms a crucial part of the process, and thus the issuing authority must ensure that no comprise is made. Provisions should be made for regular reporting of the project performance after issuance, especially in forecasted finances and real-time reconciliations. Where investors are confident of all these measures being satisfied, the success of a green bond package for renewable energy developments is high.

Other highly ranked significant factors of fixed-rate of return, access to larger investor pool and enhanced CSR also highlight added considerations to be made. It is the case that the assured return rates provide investors with some form of security concerning their earnings. The access to a larger investor pool is favorable more on the issuer side, as earlier studies have considered green bond to be a market deepening mechanism. CSR is as part of corporate governance has proven to be positively correlated to performance. Thus, committing to mitigating climate projects offer similar benefits to both issuers and investors. However, the non-significant variables of diversified investment portfolio, growing investor demand for green investments, and promoting environmentally conscious investments seem to conflict with the earlier discussed. However, it may be the case that, within Ghana, most of the focus of investment is on the "returns" aspect rather than on the "image" aspect. Lowly ranked variables of significance- flexibility in issuance and oversubscription of issuances globally - reiterate the earlier stated point. Though these are factors to look out for, findings from investor responses suggest that much priority is given to project feasibility and economic viability.

The findings theoretically contribute to the initial framework proposed for the study. By considering, the features considered as significant and preferential to Ghanaian investors, this present research study attempts a categorization of the features in accordance to the investor motivating factors by Maltias and Nykvist (2020). 


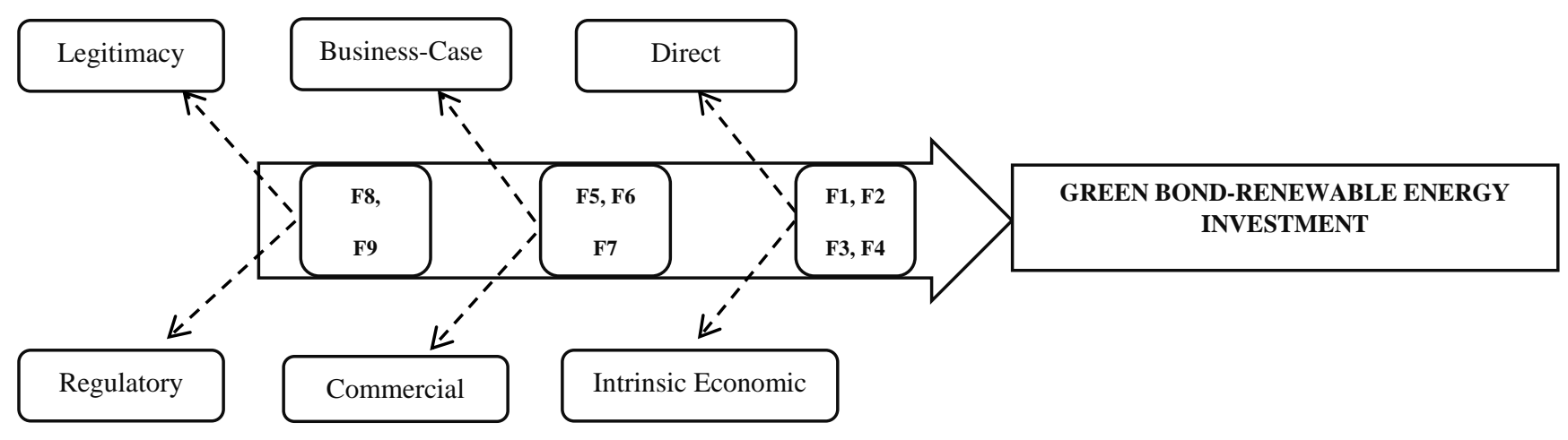

Figure 2. Theorised findings framework

Source: Authors' Construct (2021)

Under Direct benefits, we categorise; Low interest rate (F1), Economic Convenience (F2) Fixed rate of return (F3), Access to larger investor pool (F4).

Under Business-case benefits, we categorise Similar payback period with RE projects (F5), Flexibility in issuance (F6), Oversubscription of issuances globally (F7).

Under Legitimacy benefits, we categorise Transparency in bond issuance (F8), Enhanced CSR (F9).

Theoretically, the new framework proposes linkages for further investigation in future studies of green bonds and for renewable energy finance in Ghana. Since the area is a developing one, research analysis to validate the green bond features and their role in linking investor preferences/motivations as well as offsetting renewable energy financing challenges is of prime importance. This will further deepen the understanding on green bonds and aid in the curation of attractive and high performing green bond packages.

Green bonds have been studied extensively within developed regions but have received scant academic attention in Ghana. As nascent as the market is here in Ghana, this study provides some of the early investor insights before the first tranche of issuances and as such, contributes to bridge the prevailing knowledge gap in this area. Specifically, this took a stance from the investors' point of view. The findings from the case of Ghana contribute to the broad existing scope of literature on green bond financing. The insights drawn from this study will be valuable to advanced research within RE and green bonds financing not only in Ghana, but also in Africa.

\section{Conclusion:}

The preferences of investors concerning the usage of green bonds to finance RE projects in Ghana are explored within the study. The earlier literature explores the current energy situation in Ghana and its commitment to increasing renewable energy capacity. The financial dynamics to achieve this is also presented in addition to the prospects and benefits of green bonds. As 
highlighted within Africa, green bond issuance remains mostly limited. The same case can be made for Ghana, with the country yet to issue its first green bond package. However, the dynamics show that coupling green bonds with renewable energy would result in high financing potential. Particularly with the similarities in the characteristics each possesses.

By exploring the financial and investment institution opinion, the study highlights key features of green bonds, exceptionally preferential should there be a package for renewable energy developments. From an extensive literature review, twelve (12) key features of green bonds are highlighted and ranked in a survey. The analysis shows that low-interest rate, similar payback period, economical convenience and transparency in issuance are the topmost features that investors should consider and preferred for a renewable energy green bond. Closely ensuring these features' availability and sufficiency will see increased chances of green bond success in the Ghanaian bond market.

The limitations of the study are premised upon its geographical context. The focus on Ghana may make it exiguous for global generalizations. The consideration of only investors may also make the findings one-sided as issuers and developers of green bonds may also have unique preferences. Further studies are required reveal the added complexities in such unique cases. Nonetheless, key insights are presented through the eyes of Ghanaian investors. As part of preliminary studies in the Ghanaian context, a foundation is presented for further studies to be built upon.

\section{References:}

African Local Currency Bond (ALCB), (2018), 'Understanding the African Green Bond Market'http://www.alcbfund.com/wp-content/uploads/2018/03/2018-03-05-African-GreenBondMarket_Final.pdf (Accessed, 25th June 2020)

Aghimien, D.O., Aigbavboa, C., Edwards, D.J., Mahamadu, A-M., Olomolaiye, P., Onyia, M., and Nash, H. (2020) A fuzzy synthetic evaluation of the challenges of smart city development in developing countries, Smart and Sustainable Built Environment DOI: https://doi.org/10.1108/SASBE-06-2020-0092

Agliardi, E. and Agliardi, R., 2019. Financing environmentally-sustainable projects with green bonds. Environment and development economics, 24(6), pp.608-623.

Alteneiji, K., Alkass, S. and Dabous, S.A., (2019). Critical success factors for public-private partnerships in affordable housing in the United Arab Emirates. International Journal of Housing Markets and Analysis, Vol 3 No. 5, pp. 753-768

Analysis of Trends and Issues in the Financing of Renewable Energy. New York: UNEP and Bloomberg.

Aninze, F., El-Gohary, H. and Hussain, J., (2018). The Role of Microfinance to Empower Women: The Case of Developing Countries, International Journal of Customer Relationship Marketing and Management, 9(1), pp: 54-78.

Asiedu, N., Adu, P., Anto, E.K. and Duodu, A., (2019). Energy economics and optimal generation mix of selected power plants technologies in Ghana. Scientific African, Vol.2, e00015. 
Bank of Ghana (2019). Licensed Banks, Representative Offices \& Their Registered Offices In Ghana - Available via; https://www.bog.gov.gh/supervision-a-regulation/register-oflicensed-institutions/banks (Accessed, 25th June, 2020)

Berson, S. (2009). FINANCE: GREEN GROWS THE PORTFOLIO: Socially responsible investment can pay off. ABA Journal, American Bar Association. Vol. 95, No. 11, pp. 2526.

Breen, S. and Campbell, C., 2016. Legal considerations for a skyrocketing green bond market. Nat. Resources \& Env't, 31, p.16.

Brunnschweiler, C.N., (2010). Finance for renewable energy: an empirical analysis of developing and transition economies. Environment and Development Economics Vol. 15, 241-274.

Brzeszczyński, J. and McIntosh, G., 2014. Performance of portfolios composed of British SRI stocks. Journal of business ethics, 120(3), pp.335-362.

Chen, K., and Reklev, S. (2014). China's national carbon market to start in 2016-Official. Reuters. Available via: http://www.reuters.com/article/2014/08/31/china-carbontradingidUSL3N0R107420140831 (Accessed, 25th June, 2020)

Cheng, B., Ioannou, I. and Serafeim, G., 2014. Corporate social responsibility and access to finance. Strategic management journal, 35(1), pp.1-23.

Chugan, P.K., Mungra, Y. and Mehta, K., (2017). Challenges and policy implications for marketing green bonds. Book titled" Consumer Behaviour \& Contemporary Marketing Strategy", (Eds.), Tripurasundari Joshi, Jayesh P. Aagja and Sapna Parashar, Excel India Publishers, New Delhi for IMNU, pp.371-384.

Clapp, C. (2014). Climate finance: capitalising on green investment trends. The Way Forward in International Climate Policy, Vol. 44, pp. 44-48.

Climate Bonds Initiative (2015). First Green Bond from Kenya: Acorn USD40m - Climate Bonds Certified,

Climate Bonds Initiative (2015). Scaling up Green Bond Markets for Sustainable Development: A strategic guide for the public sector to stimulate private sector market development for green bonds. Consultation paper. Collier, P. and Venables, A. J. (2012). Greening Africa? technologies, endowments and the latecomer effect. Energy Economics, Vol. 34, No. 1, pp $75-84$

Climate Bonds Initiative (CBI) (2013). "Overview: The dawn of an age of green bonds.

Cochu, A., Glenting, C., Hogg, D., Georgiev, I., Skolina, J., Eisinger, F., Jespersen, M., Agster, R., Fawkes, S. and Chowdhury, T., 2016. Study on the potential of green bond finance for resource-efficient investments. Report, European Commission.

Companies, and Investors Unlock the Potential of the Green Bond Market? Journal of Risk and Financial Management, Vol. 13, No. 3

Creswell, J. (1994). Research Design: Qualitative and Quantitative Approach. Sage.

Dawson, C., (2009). Introduction to research methods: A practical guide for anyone undertaking a research project. Hachette UK.

Deloitte T. T. (2017). Project Bonds: An alternative source of financing infrastructure projects. https://www2.deloitte.com/za/en/pages/finance/articles/project-bonds-an-alternativetofinancinginfrastructure-projects.html\# (Accessed; 23rd November, 2018)

Deschryver, P. and De Mariz, F., 2020. What future for the green bond market? How can policymakers, companies, and investors unlock the potential of the green bond market?. Journal of risk and Financial Management, 13(3), p.61. 
Duru, U. and Nyong, A. (2016). Why Africa needs green bonds. Africa Economic Brief, Vol. 7, No. 2 , pp. 8

Edjekumhene, I., Amadu, B. A., and Brew-Hammond, A. (2001). Power Sector Reform in Ghana: The Untold Story.

Edwards, D. J. and Holt, G. D. (2009). Construction plant and equipment management research: thematic review. Journal of Engineering, Design and Technology, 7(2), pp. 186-206. DOI: $10.1108 / 17260530910974989$

Edwards, D. J., Pärn, E. A., Sing, C. P. and Thwala, W.D. (2019) Risk of excavators overturning: determining horizontal centrifugal force when slewing freely suspended loads. Engineering, Construction and Architectural Management. 26(3), pp. 479-498. DOI: https://doi.org/10.1108/ECAM-03-2018-0125

Electric utility generating units; final rule. Federal Register, Vol. 80, No. 205, pp.64662-65120.

El-Gohary, H, (2010). E-Marketing: Towards a Conceptualization of a New Marketing Philosophy - Book Chapter, in the book: E-Business Issues, Challenges and Opportunities for SMEs: Driving Competitiveness, edited by Manuela Cruz-Cunha and João Eduardo Varajão, IGI Global, USA.

El-Gohary, H, (2012). Factors affecting E-Marketing adoption and implementation in tourism firms: An empirical investigation of Egyptian small tourism organizations, Tourism Management, 33 (5), pp: 1256-1269

Elliott, T. and Zhuang, M. (2014). The greening of the corporate bond market. S\&P Research, NO. 44, pp.1-11.

Energy Commission of Ghana (2016a). National Energy Statistics (2006-2016). Retrieved from Energy Commission of Ghana.

Energy Commission of Ghana (2016b) Energy (Supply and Demand) Outlook for Ghana: Final Report, Accra, Ghana: Republic of Ghana.

Energy Commission of Ghana (ECG) (2017) Energy (Supply and Demand) Outlook for Ghana: Final Report, Accra, Ghana: Republic of Ghana.

Energy Commission of Ghana (ECG) (2020) Energy (Supply and Demand) Outlook for Ghana: Final Report, Accra, Ghana: Republic of Ghana.

Environmental Protection Agency. (, 2015). Carbon pollution emission guidelines for existing stationary sources:

Ernest and Young (EY), (2016), 'Green Bonds a Fresh Look at Financing Green Projects'

European Commission. (2010). Communication from the commission. Europe 2020: A European strategy for smart, sustainable, and inclusive growth. Brussels: European Commission.

EY. 2018. Green Bonds: A Fresh Look at Financing Green Projects. London: EY. http://www.ey.com/ Publication/vwLUAssets/Green_bonds-a-fresh-look-at-financinggreen-projects/\$FILE/EYGreen\%20bonds-a-fresh-look-at-financing-green-projects.pdf

Falsen, C. and Johansson, P., (2015). Mobilising the debt market for climate change mitigation. Experiences from the early Green Bonds market (Master's thesis).

Firelake Capital (2012), Financing Low-Carbon Energy Infrastructure: Scaling Capital and Mitigating Risk for Renewable Energy Deployment'.

Fisher, L., Edwards, D. J., Pärn, E. A. and Aigbavboa, C. O. (2018) Building design for people with dementia: a case study of a UK care home. Facilities, 36(7/8), pp. 349-368. DOI:10.1108/F-06-2017-0062 
Flammer C., (2018), 'Green Bonds Benefit Companies, Investors, And the Planet' Harvard Business Review. https://hbr.org/2018/11/green-bonds-benefit-companies-investors-andthe-planet.

Freeman, R.E. and McVea, J., 2001. A stakeholder approach to strategic management. The Blackwell handbook of strategic management, pp.189-207.

Griffith-Jones, S., Ocampo, J.A. and Spratt, S., (2012). Financing renewable energy in developing countries: mechanisms and responsibilities.

Gyamfi, S., Diawuo, F.A., Kumi, E.N., Sika, F. and Modjinou, M., (2018). The energy efficiency situation in Ghana. Renewable and Sustainable Energy Reviews, Vol. 82, pp. 1415-1423.

Hebb, T. (2012). The next generation network responsible investing. Ottawa: Springer Science + Business media BV. No. (1).

Hussain, J., Sandhu, N., El-Gohary, H., and Edwards, D. (2020). The Reality of Financing Small Tourism Firms: The case of Indian Tourism SMEs, International Journal of Customer Relationship Marketing and Management, 11(1), pp: 64-80.

IPCC (2011). IPCC special report on renewable energy sources and climate change mitigation. Cambridge University Press, Cambridge, United Kingdom and New York, NY, USA. http://srren.ipccwg3.de/report. (Accessed, 25th June, 2020).

Iqbal, T, and El-Gohary, H, (2014), Quality Management and Productivity: Concepts, Trends, Theoretical Frameworks and Implications, Germany, LAP Lambert Academic Publishing

Junkus, J. and Berry, T.D., 2015. Socially responsible investing: a review of the critical issues. Managerial Finance.

Kidney, S. and Oliver, P., 2014. Greening china's financial markets growing a green bonds market in China: reducing costs and increasing capacity for green investment while promoting greater transparency and stability in financial markets. The International Institute for Green Development. International Institute for Sustainable Development. February.

Kothari, C.R. (2004). Research Methodology Methods and Techniques, New Age International (P) Ltd, New Delhi.

Krüger, P., 2015. Corporate goodness and shareholder wealth. Journal of financial economics, 115(2), pp.304-329.

Kulkarni, S.S., Edwards, D.J., Chapman, C., Pärn, E.A., Cornish, R. and Aigbavboa, C. (2018) Evaluation of vehicle lightweighting to reduce greenhouse gas emissions with focus on magnesium substitution. Journal of Engineering, Design and Technology, 16(6), pp. 869888. DOI: https://doi.org/10.1108/JEDT-03-2018-0042

Kumar, A. (2011). Research and Writing Skills. New York, NY: Lulu Press. (978-1-44660560-8)

Kumi, E.N. (2017), The Electricity Situation in Ghana: Challenges and Opportunities. Center for Global Development.

Langhelle, A.H., 2016. Green Bonds-A change in preferences toward green investments? (Master's thesis).

Li, Z., Tang, Y., Wu, J., Zhang, J. and Lv, Q., 2020. The interest costs of green bonds: Credit ratings, corporate social responsibility, and certification. Emerging Markets Finance and Trade, 56(12), pp.2679-2692.

Liaw, K.T., 2020. Survey of Green Bond Pricing and Investment Performance. Journal of Risk and Financial Management, 13(9), p.193.

Maltais, A. and Nykvist, B., 2020. Understanding the role of green bonds in advancing sustainability. Journal of Sustainable Finance \& Investment, pp.1-20. 
Mankata, L.M., Owusu-Manu, D.G., Hosseini, M.R. and Edwards, D.J., 2020. Analysis of successdependent factors for green bond financing of infrastructure projects in Ghana. Journal of Sustainable Finance \& Investment, pp.1-17.

McWilliams, A. and Siegel, D., 2001. Corporate social responsibility: A theory of the firm perspective. Academy of management review, 26(1), pp.117-127.

Milford, L., Saha, D., Muro, M., Sanders, R. and Rittner, T. (2014), Clean Energy Finance Through the Bond Market. Brookings Institution, Brookings Rockefeller Project on State and Metropolitan Innovation.

Moore, D. S., Notz, W. I., and Fligner, M. A. (2015). The basic practice of statistics. Macmillan Higher Education.

National Insurace Commission, (2018). 2017 Annual Report and Financial Statements. Available via; http://nicgh.org/procurement-notices/annual-report/ (Accessed, 25th June, 2020)

Nazir, F., Edwards, D., Shelbourn, M., Martek, I., Thwala, W., and El-Gohary, H., (2020). Comparison of Modular and Traditional UK Housing Construction: A Bibliometric Analysis, Journal of Engineering, Design and Technology, 19(1), pp: 164-186

Newman, C., Edwards, D.J., Martek, I., Lai, J. and Thwala, W.D. (2020) Industry 4.0 Deployment in the Construction Industry: A Bibliometric Literature Review and UK-based Case Study, Smart and Sustainable Built Environment DOI: https://doi.org/10.1108/SASBE-02-2020$\underline{0016}$

Ng, T.H. and Tao, J.Y., 2016. Bond financing for renewable energy in Asia. Energy Policy, 95, pp.509-517.

Nkwocha, O., Hussain, J., El-Gohary, H. Edwards, D. and Ovia, E. (2019). Dynamics of Group Lending Mechanism and the Role of Group Leaders in Developing Countries: Evidence from Nigeria, International Journal of Customer Relationship Marketing and Management, 10(3), pp. 54-71

Norušis, M.J. (2012). IBM SPSS statistics 19 statistical procedures companion Upper Saddle River, NJ, USA: prentice hall. Vol. 496

Oikonomou, I., Brooks, C., and Pavelin, S. (2014). The effects of corporate social performance on the cost of corporate debt and credit ratings. The financial review, pp.49-75.

Olanrewaju, O., Chileshe, N. and Edwards, D. J. (2020) Estimating on-site emissions during ready mixed concrete (RMC) delivery: A methodology. Case Studies in Construction Materials. DOI: https://doi.org/10.1016/j.cscm.2020.e00439

Owens, L. (2002). Introduction to Survey Research Design. Published on Research Gate, New York

Owusu-Manu, D., Asiedu, R., Edwards, D., Donkor-Hyiaman, K., Abuntori, P., and El-Gohary, H. (2019). An Assessment of Mortgage Loan Default Propensity in Ghana, Journal of Engineering, Design and Technology, 17(5), pp. 985-1017.

Owusu-Manu, D., Debrah, C., Antwi-Afari, P., and Edwards, D.J., (2019), August. Barriers of Project Bond Initiatives in Infrastructure Financing in Ghana. In The Construction Industry in the Fourth Industrial Revolution: Proceedings of 11th Construction Industry Development Board (CIDB) Postgraduate Research Conference (pp. 12). Springer.

Owusu-Manu, D.G., Mankata, L.M., Debrah, C., Edwards, D.J. and Martek, I., 2021. Mechanisms and challenges in financing renewable energy projects in sub-Saharan Africa: a Ghanaian perspective. Journal of Financial Management of Property and Construction.

Panda, P., 2017. Green Bond A Socially Responsible Investment (SRI) Instrument. Research Bulletin, 43(1), pp.97-113. 
Park, H. M. (2015). Hypothesis testing and statistical power of a test.

PBL - Netherlands Environmental Assessment Agency. (2015). Trends in global CO2 emissions: 2015 report.

Raghubansie, A., and EL-Gohary, H. (2021). Digital Advertising Creative Processes and Innovation in UK SME Advertising Agencies: An Empirical Investigation of Viral Advertising, Scientific Journal for Financial and Commercial Studies and Research, Faculty of Commerce, Damietta University, 2(1)1, pp.75-116.

Raghubansie, A., El-Gohary, H, Samaradivakara, C. (2013). An Evaluation of the Viral Marketing Research, International Journal of Online Marketing, 3(4), pp: 1-27.

Reboredo, J.C., Ugolini, A. and Aiube, F.A.L., 2020. Network connectedness of green bonds and asset classes. Energy Economics, 86, p.104629.

REN21. (2013). Renewables 2013: Global status report. Paris: REN21 Secretariat. Retrieved from www.ren21. net/portals/0/documents/resources/gsr/2013/gsr20 13_lowres.pdf (Accessed, 25th June, 2020)

Rogelj, J., den Elzen, M., Höhne, N., Fransen, T., Fekete, H., Harald Winkler, H., Meinshausen, M. (2016, June 30). Paris agreement climate proposals need a boost to keep warming well below 2? ${ }^{\circ} \mathrm{C}$. Nature, Vol. 534, pp. 631-63

Ross, U., 2015. Green bond drivers. London: HSBC.

Saha, D. and d'Almeida, S., 2017. Green municipal bonds. Leaders, 5(98), p.886.

Sartzetakis, E.S., 2020. Green bonds as an instrument to finance low carbon transition. Economic Change and Restructuring, pp.1-25.

Schmidt, T. S. (2014), Low-carbon investment risks and de-risking. Nature Climate Change, Vol. 4, No. 4, pp. 237-239.

Schwerhoff, G. and Sy, M., (2017), Financing renewable energy in Africa-Key challenge of the sustainable development goals. Renewable and Sustainable Energy Reviews, Vol. 75, pp. 393-401.

Seo, S. N. (2017). Beyond the Paris Agreement: Climate change policy negotiations and future directions. Regional Science Policy \& Practice, Vol. 9, No. 2, pp. 21-140.

Shishlov, I., Morel, R. and Cochran, I., 2016. Beyond transparency: unlocking the full potential of green bonds. Institute for Climate Economics, pp.1-28.

Sievänen, R., Hannu, R., and Scholtens, B. (2012). The drivers of responsible investment: The case of European pension funds. Journal of Business Ethics, pp.137-151

Silva, F. and Cortez, M.C., 2016. The performance of US and European green funds in different market conditions. Journal of Cleaner Production, Vol. 135, pp.558-566.

Singh, A.S. (2017), "Common procedures for development, validity and reliability of a questionnaire", International Journal of Economic, Commerce and Management, Vol. 5, pp. 790-801

Sonntag-O'Brien, V. and Usher, E. (2013), January. Mobilising Finance for Renewable Energies. Thematic Background Paper for the International Conference for Renewable Energies. In Secretariat of the International Conference for Renewable Energies. Bonn, Germany, Vol. 14.

Sonntag-O'Brien, V., Usher, E., (2006), Mobilising finance for renewable energies. Renewable Energy: A Global Review of Technologies, Policies and Markets, Earthcan, London pp. 169-195.

Talal F. S., Walid S. and Abdelrahim A. (2016), 'Green Bonds' CEDRO - 'Empowering Lebanon with Renewable Energy.' 
Talbot, K.M., 2017. What Does Green Really Mean: How Increased Transparency and Standardization Can Grow the Green Bond Market. Vill. Envtl. LJ, 28, p.127.

Tang, A., Chiara, N. and Taylor, J.E., (2012), Financing renewable energy infrastructure: Formulation, pricing and impact of a carbon revenue bond. Energy Policy, Vol. 45, pp. 691-703.

Tang, D.Y. and Zhang, Y., 2020. Do shareholders benefit from green bonds?. Journal of Corporate Finance, 61, p.101427.

Teske, S., 2019. Achieving the Paris climate agreement goals. Springer International.

UNDP (2013), De-risking Renewable Energy Investment. Technical report, UNDP.

UNEP (2012), Financing renewable energy in developing countries - United Nations Environment Programme Finance Initiative.

UNEP and Bloomberg New Energy Finance (2018), Global Trends in Renewable Energy Investment 2018.

UNFCCC. (2015, December 12). Paris agreement (FCCC/ CP2015/L.9/Rev.1, 12). Retrieved from https://un fccc.int/resource/docs/2015/cop21/eng/109r01.pdf

Ur Rahman, R., Shah, S., El-Gohary, H., Abbas, M., Khali, S., Al Altheeb, S., and Sultan, F., (2020). Social Media Adoption and Financial Sustainability: Learned Lessons from Developing Countries, Sustainability, 12(24), pp: 27-52.

USAID (2018), AFRICA - Ghana Power Fact Sheet. https://www.usaid.gov/powerafrica/ghana (Accessed, 25th June, 2020)

Walliman, N. (2011). Research Methods the Basic, Routledge, London.

Wang, E.K., 2017. Financing Green: Reforming Green Bond Regulation in the United States. Brook. J. Corp. Fin. \& Com. L., 12, p.467.

Wiśniewski, M. and Zieliński, J., 2019. Green bonds as an innovative sovereign financial instrument. Ekonomia i Prawo. Economics and Law, 18(1), pp.83-96.

World Bank (2021). Access to electricity (\% of population) - Sub-Saharan Africa. Available via: https://data.worldbank.org/indicator/EG.ELC.ACCS.ZS?locations=ZG (Accessed, 25th January, 2021)

Zachariah, R., (2016). 5 Things to Know About Green Bonds. ET Bureau. Retrieved from http://siteresources.worldbank.org/EXTENERGY2/Resources/SREP_financing_instrume nts_sk_clean2_FINAL_FOR_PRINTING.pdf (Accessed, 25th June, 2020)

Zaki, A., El-Gohary, H., and Edwards, D., (2021). Understanding Ethical and Other SMEs Internationalisation Determinants and its Impact on Business Performance: A Primary Attempt to Understand Malaysian SMEs Internationalisation, International Journal of Customer Relationship Marketing and Management, 12(1), pp: 1-27

Zhou, X. and Cui, Y., 2019. Green bonds, corporate performance, and corporate social responsibility. Sustainability, 11(23), p.6881. 